\title{
言語連想検査の感情反応についで
}

一東京家庭裁判所瓜生武一

1. 早大式言語連想検査の構成、日常語の名詞 100 語 の刺戱語から成る。刺戱語はりんご，さんすう，な九 が，ちやわれ，うし，光いが、びえぼう，よる etc.

刺㦸の与方は，集団法では刺戱語の印刷してある用 紙をくぼり，被験者はそれを目読して反忘語を空欄住記 大する。又個人法では刺战語を検查者が読み，被験者は

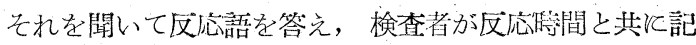
録する。反応㭙間は刺戲語の読終りから反応語発声迄の 㬨間を 1 秒単位で測定する。

教示嗰人法では “こちらで短い言葉を幾つか云いま すから，との一つ一つを聞いて最初思いついた事を何 でもよいですから出来るだけ早く答えて下さい”と云う 意味のもので，集団法で路此の他若干の例を示す。

整理法は研究の途上で多少の变更を見，且つ多角的な 見方以移行しつ口あるが，火の基本となるものは，次の 分類法である。

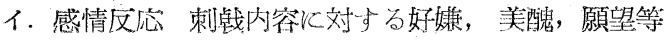
0記述。

口. 性状反応 刺戲内容の性質, 状態の記述。

八. 敘述反応 主として固有経験基き，刺㦸内容に 本質的でない性質, 状態烊びそ評侕の記述と自己本位な 定義づけ。

二、動作反応 刺皒内容《対する動作の記述。

ホ. 上位反応 刺戱語の上位概念飞当る。

一。添加反応 添加とよる成語の構成，但し他の項目 飞分類されるもの孝除く。

卜，同一反応 刺战言吾の同義異榼。

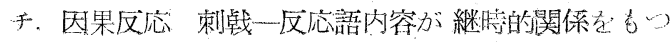

リ. 反刘反応 同位概念中の対概念江当\%。

又. 類纠反応 同位概念で, (リ)に非ざるもり。

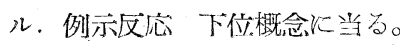

ヨ. 要素反応 刺戱一民応語内容が 構成部分↔全体乃 至, 忉料↔生成物の関係をもつ。

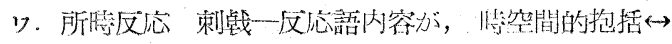
被创括関係をもつ。

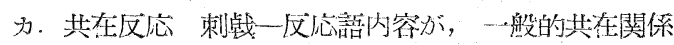

* 此の資料性早槄由大学心理学研究室飞於いて, 潮 田武彥, 桜井謙蔵, 山本研一, 内田㭧哉, 瓜生武 が戸川行男教授の指導の下に行つた研究並びに符 19回大会行於いて山本碚一，瓜生武が発表した共

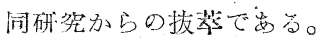

をもつ。

ヨ. 印象反応印象に於ける類似性をもつ。

タ. 模字反応 形態のみ飞類似性をもつ。

レ. 間接反応 刺钱一反応語内突を関係づけるのと，

一・二の中間項 (仲介語) を必要とする間按的関連性を

$=0$

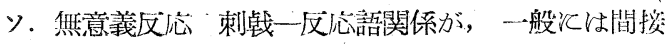
的汇も理解出来ないもの。

ツ。音無意義反応 言語音上のみの類似性。

(ヨ・タ・ソ・ツは稀有反応, イ一父内連合, チ一 夕を外連合，イ・八・二を主体的反応，コ・ワ・カを客 観的反店として群化する事ありつ。

2. 解釈法の基礎的観点 言語連想反応をバーソナリ テイ診断と応用すると当つて，個々の刺战一反応語内容 が示す経験の連関性炕関する過去の補強関係よりも， 全 仅応を通じ示される刺戲の受取り方，乃至連想過程に働 くその個人固有の選択傾向を重視した。

3. 感情反応について 通常 “連想” 上云う場合には 客観世界の或事物を契㙨として他の事物が想起される事 を指し，上記分類法の上では外連合反応がこれに当る。 そして我々の教示の中に“斬想”之云方言某が使われな いでも，この外連合反応性人正常者の反応で約 $60 \%$ を 占め, 最も正常性の高い反応としての様相走示してい \%。これと対して感情反応注分類の上では事物汇対する 主体的反応 (感情) の敍述と云亏点で，事物対象間の関 倸である客観的反応之対立し，一方反応頻数関可る因 于纷析結果 (Table. 1.) ても, 第 1 軸に於いて刘称的に 位置らけられる事が判明した。そこで言語連想に対する 我々の前記倠点からの診断価值研究の第一歩として, 今 汽な連想でないとして捨てられて居た此の感情反応を対 象以選び，若干门研究結果を得たので 資料上して提供す ప。

4. 感情反応の特徵 (1) 亿，他の分類別反心頻数 との相関並びを因子分析。小学生1166名0反応を上記 19 項目以分類, 頻数相関係数を算出し, サーストンの重因 子分析走行つた結果定 Table. 1. 绎与。

口. 発荎美及び非行群上の比較。感情反応山青年期汇

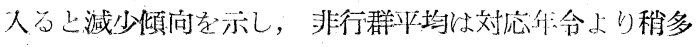

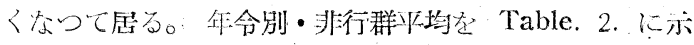
s. 
Table. 1. 感情反応との頻数相関及び分類別反応頻数の重因子分析

$\mathrm{n}=1166$

\begin{tabular}{|c|c|c|c|c|c|c|c|c|c|c|c|c|c|c|c|c|}
\hline & & 感情 & 性状 & 敍述 & 動作 & 上位 & 添加 & 同一 & 因果 & 反対 & 類似 & 例示 & 要素 & 所時 & 共在 & 間接 \\
\hline $\mathrm{r}$ & & - & +.00 & -.05 & -.35 & -.39 & -.28 & -.21 & .25 & 45 & -.48 & -.51 & -.60 & -.63 & -.54 & -.44 \\
\hline & & +.99 & +.22 & +.23 & +.13 & -.14 & -.19 & +.03 & -.14 & -.69 & -.59 & -.69 & -.73 & -.79 & -.64 & -.37 \\
\hline 子 & II & +.00 & -.70 & +.04 & +.63 & +.38 & +.35 & +.36 & -.00 & +.30 & -.02 & -.06 & -.07 & -.05 & -.13 & +.05 \\
\hline 軸 & III & +.00 & -.02 & -.06 & -.05 & -.25 & -.14 & -.26 & -.11 & +.54 & -.63 & -.19 & +.28 & +.20 & -.29 & -.21 \\
\hline
\end{tabular}

Table. 2. 感情反応標淮頻数

\begin{tabular}{l|l|l}
\hline & n & A. M. \\
\hline 小学 4 年 & 282 & 17.3 \\
小学 5 年 & 177 & 22.6 \\
小学 6.年 & 158 & 25.5 \\
中学 生 & 514 & 22.7 \\
高 校 生 & 416 & 18.1 \\
大学 生 & 244 & 10.6 \\
教護院收容少年 & 48 & 23.6 \\
鑑別所收享少年 & 84 & 26.4
\end{tabular}

八. 異常群の特徵。精神病・神経症患者 47名の総平均 上正常との差及び疾病別の平均善怯䜅め難いが，感情反 応 $35 \%$ 以上の高頻度者 6 名が女性つ夕炕誌められた点が 特徵的である。

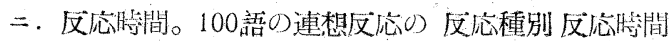
平均老, 各人の全反応㭙間平均炇対する访分比で示し, これを大学生100名の記録について平均したものが Table

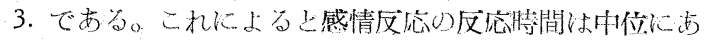
り, 言語反応が速い。

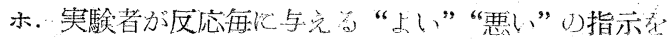
聞きながら，どの上うな傎向で反応すればよいかを試行 錯誤的认発見すると云う課題の実験で，後半は指示をす ンダムにする事で不解沃場面を班成, 被験者をフラスト レートせしめた時, 大学生つ被験者 23 名中12名は感情反 応が増加し，5名は減少，6名が概枋恒常であうた。な 扔我々の臨床経験によれば, 感情反忘の頻数法他の反応 《比して場面からり影響を受计易いもりり上うである。

5. 感情反応の特徵 (2) 同，被験省伦ついて連想检

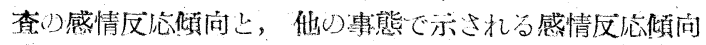

との相関を見る方法を行つた。被験者山交京区立中学 3 年生, 男子50名女子-50名で, 連想検查と同㭙飞次の三種 類の比較検查を施行した。

イ、体験想起 びんせん，なつ，特いしやさん等8 8 語 を与えて，各々飞関連する具体的思い出を出来るだけ沢 山書けと云う教示で, 1 讙 3 分の割合で施行, その次に 今思い出した体験が各々快体験であるか，不快であか， 中性であるかを分類せしめ，快又山不快汇分類したもの の全反応数汇対する分分比で，この検查の感情反伈傾问 を示した(指数イ.)。

口. 非情緒的中性刺钱に対与当感情的把握。数字，似 名, 口ーマ学, 図形, 記号等 合計 100 ケの概祄情緒的反 忘を伴わな以と考えられる刺战を印刷し，その备々を好 - 嫌・中性の別以分類せ乙めた。この結果，好・嫌沉分 類された刺戲数を以つて，この検查つ感情反応指数(口) とした。

八.日常生活心感情調 日常生活事態で诎会う品物・ 事柄で，通常多少とも感情反応を伴うょうな事項，例兄 ばけんか，赤ん坊汇さわられる，ガソリンの旬，蛙 等

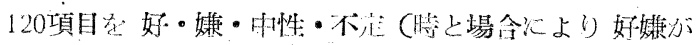

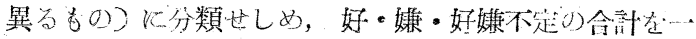
般的感情反応の指数 (…1) とし，好・媒のみの合計 を好嫌の二価的把握の態度の指数 (ハ-2) として特別 飞扱つた。な招120項目の刺戱は反復されて居り，最遅 者が 120 項目を終了した時汇打切れば，既済の項目数沉

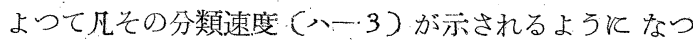
て居る。この指数は好嫌の二洒的把握の容易さ走示す 山上考兑た。

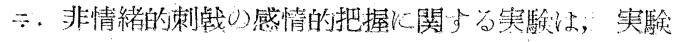

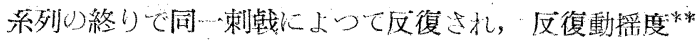

Table. 3. 反公時简比平均 $\frac{1}{\mathrm{n}} 2 \frac{\text { 分類別 R. T. 平均 }}{\text { 全 R. T. 平均 }} \times 100 \quad \mathrm{n}=100$

\begin{tabular}{|c|c|c|c|c|c|c|c|c|c|c|c|c|c|c|c|c|}
\hline & 感情 & 性状 & 敘述 & 動作 & 垃 & 添加 & 同 - & 因果 & 反刘 & 類似 & 例示 & 要素 & 所時 & 共在 & 間接 & 無意義 \\
\hline A. M. & 105 & 102 & 109 & 144 & 106 & 87 & 101 & 117 & 86 & 91 & 135 & 106 & 1.09 & 105 & 121 & 143 \\
\hline
\end{tabular}




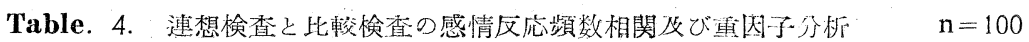

\begin{tabular}{l}
\hline \\
\hline $\mathrm{r}$
\end{tabular}

の大きいものは検査と当つての反心態度がいいかげんの 者であると予想した。

以上の諸指数と連想険查の感情反忘(願望反応を除く) との相関係数汢，Table.4. と示した。これによると相関 值は一航て低いが， $\mathrm{t}$ 検定の結果，体験想起及び日党生 活の一船的感情謂の指数との間には，1\%以下の危険率 で力意㥵関が琶められた。しかしこれらの指数㥵互間の 相関係数在求めて重因于分析を行うと，連想，日党星活

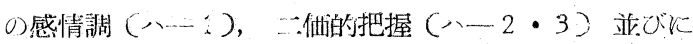
非情緒的刺戯分感情的把握(口) の指数が，各々異る軸

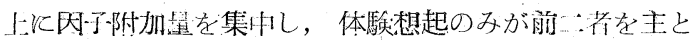
与る軸上《少量の因于量の分散考示している(Table. 4)。 従つて連想㰸查の感情反心流，体駼想起を除く他の諸指 数が示すものとの間に，殆ど共通因于を持たない之考え られる。

更感情内容, 即ち快・不快の比を, +3 加-3汽 の 7 段階***区分し，その一致度を $\chi^{2}$ 検定した所，連 想, 体験想起, 日常生活の感情調の 渚の間飞 有意惆関
Table. 5. 連想検查と比較検査の感情反応内 容の相関検定 $\mathrm{n}=100$

\begin{tabular}{|c|c|c|c|}
\hline & 連 想 & 1 & ㅁ \\
\hline 1 & $75.80^{*}$ & - & - \\
\hline 口 & 40.64 & 39.15 & - \\
\hline 八 & $94.94^{*}$ & $52.07^{* k}$ & 40.89 \\
\hline & $\begin{array}{l}\chi^{2}, \quad * \\
* *\end{array}$ & で有意相 & \\
\hline
\end{tabular}

が諰められた(Table. 5.)。

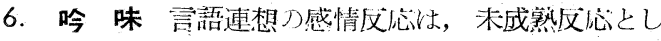
ての意味を持つようである。しかし成熟後の此の反店は 安易な, いい加減の反応態度を意味するのではなく，日 常生活の感情調とか，過去体験の想起於将る感情反忍 傾向と僅かながら共通因于を持つと云う意味で，質量と もと個々の刺戱内容飞対する好嫌と云う結びつきを超光 た “全般牨感情反灾傾问”，としての意朱を持つと考兄ら れ゙る。

\section{性度に関する諸問題 $(\mathbf{I})$, 年齡 と性度}

一同志社大学 野上若 彦—

目的 ターマンは「罗性性格及び女性性格は人格の 属性ではなく，むしろ中核をなすものである」といつて いる(1)が，確かにそれは個人の人格形成の上飞大きな 意義を有している。之を数量的测定しょうと試みたも のが性度知査であり，性度評定の研究としては Storong の The Storong Vocational Interest Blank Test(5); Terman と Milesによる The Attitude-Interest Analysis Test (1, 2); Hathaway ¿ McKinley の M.

\footnotetext{
**2(快↔不快) +(快又八不快↔中性) 項目数

***+3 快不快 が 3.5 以上

+2 快不快 が $2.5 \sim 3.4$

+1 快/不快 が $1.5 \sim 2.4$

$-1 \sim-3$ は逆の対忍，その間が \pm 0
}

M.P.I. による男性尺度がある。我国のものとしては 松井三雄上の「遊戯飞よる性度の判定」(8); 渡辺徹・村 中兼松氏の厂性度検查」(9); 小保内虎夫 - 松岡武氏の 「色彩象徵法性格㭘査(C.S.T.) 飞上る性度の測定」(10) 並びに南条正明氏による $\mathrm{N}-\mathrm{N}$ 式性度娭査(11)等が見られ るが，私は性度が個人の人格形成の上にどの様な形で現 われてくるのかという問題や，発達的な意味に於いて各 年令層飞現われてくる性度の諸相を眺めて見る事を目的 とし，同時にターマン及び村中氏の研究結果と㹿せ三者 の比較検討をも試みた(12)。今回は学生を中心とした中 学加与大学迄の年命層と, 10 藏加 40 藏迄の一般社会人 を対象として Table. 1. 飞示す約 3000 名の被駼者の中 からその結果を整理した。 